\title{
Earth's crude mosaic
}

\section{How plate tectonics triggered a seismic upheaval in geology.}

\section{The Earth: An Intimate History by Richard Fortey \\ HarperCollins: 2004. 502 pp. 225 . To be published in the US by Knopf in November. \\ Gordon L. Herries Davies}

Neither names nor place will I reveal, but the year was 1968. We had just heard a lecture delivered by a geological bigwig of the day. His subject had been the new geological synthesis, and he had preached the gospel of plate tectonics. As we left the auditorium, one of my colleagues - a noted palaeontologist - commented: "He really seems to take all this quite seriously!"

My colleague was not unique. We were living at the time amidst a revolution in geological thought. Our intellectual world was experiencing massive seismic upheaval. Those of us raised on the first edition of Arthur Holmes' Principles of Physical Geology had once marvelled at the daring that had allowed him to devote a whole final chapter to continental drift. Yet by the 1960 s we were being told that our continents ride mobile plates as performers ride their bucking mounts in some Western rodeo. Exciting stuff. I feel it a great privilege to have been an Earth scientist during a period when geology sprang back into vigorous life after well-nigh a hundred years of semiparalytic lethargy.

An eminent palaeontologist, Richard Fortey has achieved an international reputation as an expositor of the Earth sciences, as the cover of his latest book emphasizes: his name appears in the same typeface as the title. In Life: An Unauthorised Biography (HarperCollins, 1997), Fortey traced the natural history of the Earth over four billion years. Now he has turned his attention to the annals of the very Earth itself. The tale has been largely rewritten since 1963, when Fred Vine and Drummond Matthews published in Nature their famed essay "Magnetic anomalies over ocean ridges”.

Fortey takes my mind still further back, to the swinging big bands of my youth. In the opening number I applaud when, under Fortey's direction, the 'bones resume their seats and the golden sax section takes over. The star trumpet inspires foot-tapping ecstasy with an up-tempo eruption. The male vocalist takes over the mike to add his gravelly contribution. And all the while the entire outfit swings forward to the exciting, thrusting beat of the rhythm section. Count Basie and Benny Goodman may have gone, but the sheer energy of Fortey's plate-tectonic rhythm section ensures that the geology big band will continue to swing before large audiences for decades to come.

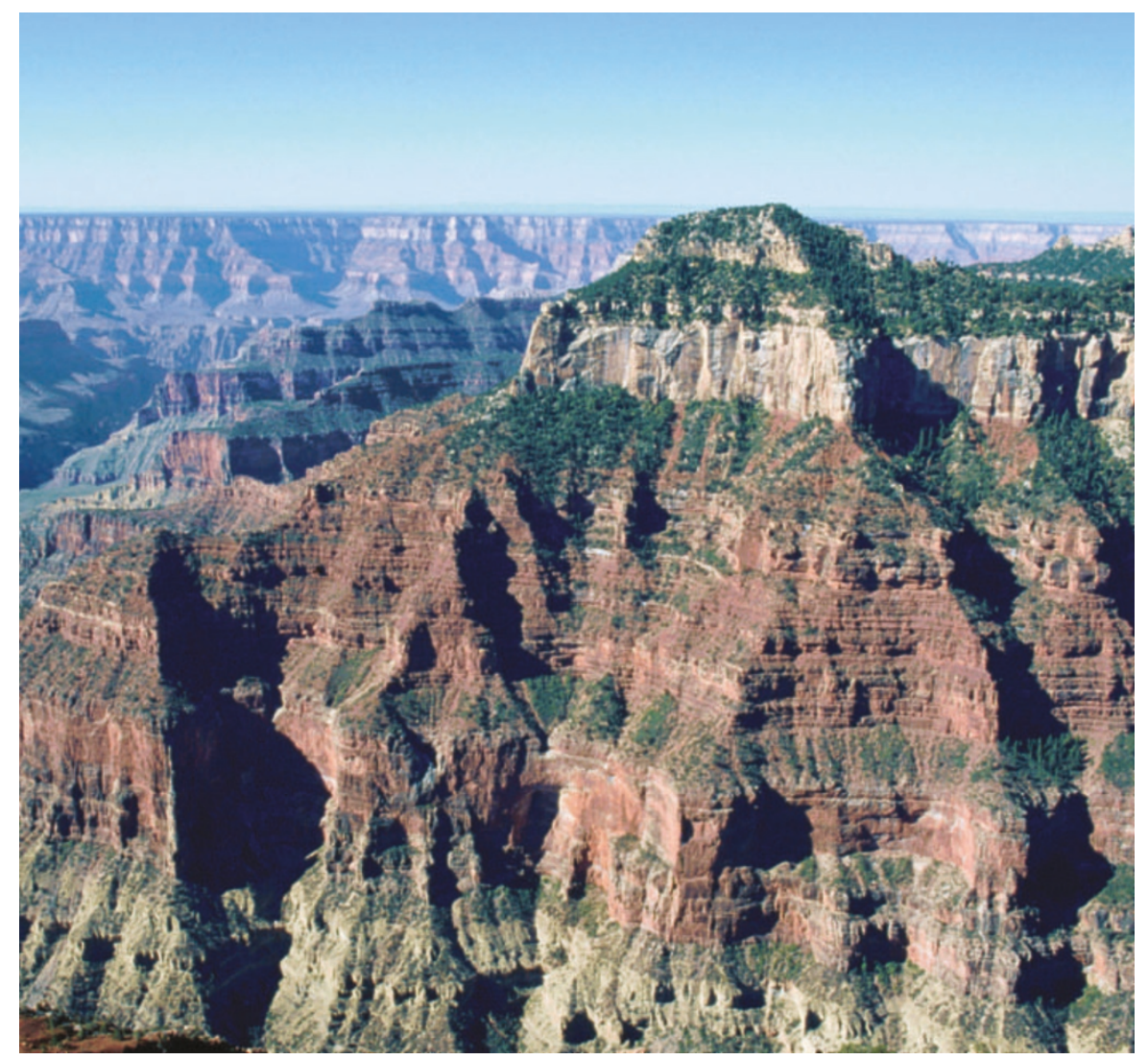

On the trail: a trip down the Grand Canyon's stratigraphy is like reading a 'diary of the Earth'.

I wholeheartedly approve of Fortey's literary strategy. He wishes us to remember that his is a field-based science. Through these pages we are taken to examine actual rocks. One illustration facing page 214 says it all five geologists confront a classic section. In days of yore they would all have sported hammers, but today we are in conservation mode and not a single hammer is to be seen.

The book is constructed around a framework of visits to specific geological locations scattered around the world. For each location, Fortey offers a clear, graphic and entertaining exposition of the manner in which, over an eon, the observed geological phenomena have achieved their present state. And he forcefully reminds us that events remotely embedded in deep time may yet be highly relevant as determinants for the lifestyles of modern human communities. And all the while, on page after page, behind Fortey's scintillating solo breaks, we hear the steady, driving beat of that platetectonic rhythm section.

The first location to which Fortey takes us is the Bay of Naples, to imbibe the lessons of Vesuvius, Pompeii and the columns of the Temple of Serapis. He finds other didactic locations in Dartmoor and Scotland's northwest Highlands, in the Czech Republic and the Alps, in the Indian Deccan traps and Hawaii, in California and Newfoundland. I have had the good fortune to visit many of Fortey's locations, and his handsomely crafted chapters evoke abundant memories. A traverse of the exposed plane of Scotland's Moine Thrust was for Ben Peach so emotional an experience that it commonly brought tears to his eyes. I feel much the same about the Grand Canyon, which also features here. Fortey terms the sequence exposed there "the diary of the earth". Never again will I hear the third movement ('On the Trail') of Ferde Grofé's Grand Canyon Suite without thinking of Buttermilk, the mule that carried Fortey down that magnificent stratigraphic ladder to the great river itself.

Everybody who has ever written a book knows that when the advance copy arrives it instantly falls open to reveal something that one wishes had been otherwise. For Fortey this must have been the NASA photograph on page 462. This is not the Gulf of Aden, as the caption claims, but the Gulf of Aqaba. I offer just one other trivial correction. Throughout the book, Fortey pays repeated and well-merited tribute to Das Antlitz der Erde by Eduard Suess. On page 26 he ascribes 
the English translation of this classic to Hertha Sollas, 'wife' of William Johnson Sollas - William did have two wives (not simultaneously), but Hertha was one of his two daughters. She was one of a talented group of ladies who studied science in Cambridge around 1900 but whose gender denied them any of the university's degrees.

The vast majority of publishers' blurbs are not to be taken seriously, but I think there may be some truth in the claim that this book "will change the way you view the world permanently". This is a work that I admire and recommend. My palaeontological colleague of 1968, although long in retirement, remains scientifically active. I will certainly be telling him how much I enjoyed my tour of Earth's crude and stitched mosaic in Fortey's excellent company.

Gordon L. Herries Davies is at Trinity College

Dublin and Ballinaclough House, Nenagh,

County Tipperary, Ireland.

\section{$\cdots \cdots \cdots \cdots \bullet \bullet \bullet \bullet \bullet \bullet \bullet \bullet \bullet \bullet \bullet \bullet \bullet$}

Whales with a

\section{nose for culture}

\section{Sperm Whales: Social Evolution \\ in the Ocean}

by Hal Whitehead

University of Chicago Press: 2003. 456 pp.

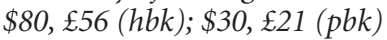

\section{Wahlberg}

More than thirty years have passed since Alfred Berzin wrote his seminal monograph The Sperm Whale (Israel Program for Scientific Translations, 1972). This book was based mainly on anatomical data obtained from whaling. Now, in Sperm Whales, Hal Whitehead enthusiastically reviews what we have learned since then about the social behaviour of these giants, owners of the planet's largest nose and brain.

Early accounts of sperm-whale behaviour came from whalers in the nineteenth century. During the revival of sperm whaling in the 1950s, several biologists, including Berzin, made a range of anatomical studies. The whales' diet was studied by analysing stomach contents, and their breeding behaviour was inferred from sexual dimorphism and the anatomy of the reproductive organs. For practical reasons, there seemed to be no other way of studying this large, deep-diving, offshore whale.

In the early 1980s, this view changed dramatically when Whitehead and Jonathan Gordon, both then at the University of Cambridge, UK, led the Tulip expedition to Sri Lanka and showed that whaling was not the only way to study this species. Population data could be gathered using photo-identification and acoustic techniques, and longterm behavioural studies gave intriguing

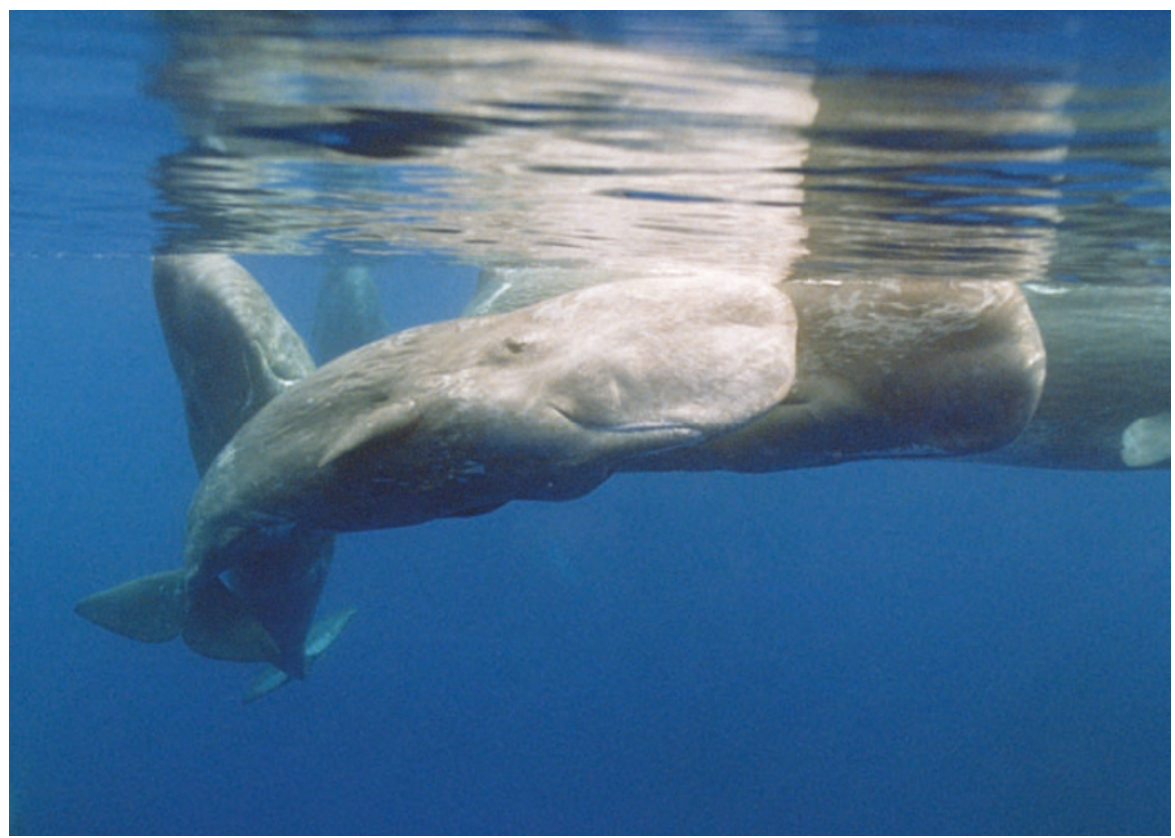

On the scent of a mystery: could the sperm whale's giant nose be used for sound production?

insights into the social lives of sperm whales. Whitehead's book is a fascinating account of what has been learned during two decades of non-lethal research inspired by the Tulip expedition. The core of sperm-whale society is now known to consist of female groups living in warm waters. When males grow up, they split from these groups and migrate towards polar waters to feed. As adults, they return to the tropics to rove among the female groups. By contrast, the females form decade-long bonds with other whales within their group. These bonds are not immediately obvious to a casual observer but have been revealed through long-term field studies.

An important part of the book deals with the animal's nose. This huge fat-container, plumbed with fire-hose-sized nasal passages and air sacs, is surrounded by a muscle layer so thick that it is possible for the whale to lift a truck with a frown, and it is innervated with nature's thickest nerve. Whitehead dismisses several of the existing theories as to its function, such as a buoyancy control mechanism or a battering ram. Instead, he favours recent acoustic work showing that the whale uses its nose for sound production, thereby associating the largest nose on the planet with the loudest sounds produced in the animal kingdom.

Sound is fundamental to the lives of sperm whales. The book summarizes the results from several studies of their acoustic repertoire. The whales use knocking sounds both for communication and to find food in the abyssal darkness. The animals use their communication sounds, called codas, to maintain contact with one another. Sympatric groups of sperm whales have different coda repertoires, and these, along with other behavioural differences, seem to be culturally transmitted between generations. Whitehead's research group at Dalhousie University in Nova Scotia is spearheading work on cultural transmission and the social evolution of this species. However, some of the conclusions drawn from their studies seem premature, considering the limited amount of data so far available. The book does not discuss the serious scepticism expressed by some scientists about these conclusions (see Behav. Brain Sci. 24, 309-382; 2001).

These few, small criticisms aside, the book is a well-written, comprehensive and much-needed sperm-whale monograph, and includes a detailed bibliography covering all aspects of current research. Whitehead's survey also reveals that many aspects of this species' behaviour remain unknown. Unlike the whalers of the 1800s, today's scientists approach the animals in a peaceful manner to find out how they are related and where and how they catch their prey. The rapid developments in genetic sampling methods and data logging mean that these techniques also can be applied to the whales. Instead of using harpoons, today's scientists use darts to obtain skin samples, and attach suction-cups linked to instruments for sampling the animals' acoustic and diving behaviour.

Whitehead's book will serve as an important source of inspiration and information for whale scientists. The book is also entertaining for the general reader, and is suitable educational material for students of marine sciences.

M. Wahlberg is in the Department of

Zoophysiology, Aarhus University,

DK-8000 Aarhus C, Denmark, and Tjärnö

Marine Biological Laboratory, Department of

Marine Ecology, Göteborg University, Sweden. 